\title{
Toward revealing the roles for intermedin in the community of vasoactive peptides
}

\author{
John J Evans \\ Hypertension Research (2009) 32, 824-825; doi:10.1038/hr.2009.127; published online 14 August 2009
}

$\mathrm{T}$ he potential of intermedin (IMD) as a regulator of cardiovascular activity is well established. For example, studies have shown that IMD exhibits vasodilatory activity $^{1}$ and decreases blood pressure. ${ }^{2,3}$ In pathophysiological states, it has been reported that the expression of IMD is enhanced during heart failure. 4 In addition, higher IMD expression in hypertrophied left ventricular cardiomyocytes suggests an important role for the peptide in the response to chronic hypertension. ${ }^{5}$

In an investigation published in this issue, Zhang et al. ${ }^{6}$ use a mouse model to study the effects of IMD in relation to the important clinical problem of myocardial ischemiareperfusion injury. The role of IMD in this pathological condition remains poorly understood, and little is known with regard to changes in the expression of IMD and the receptor components. In the current investigation, the authors use a mouse model involving ligation of the left descending artery. They report that there are changes induced in pulse pressure and heart rate following induction of infarction and reperfusion. With respect to furthering our understanding of ischemia-reperfusion, it is important to note that there were also changes in factors associated with IMD. Observations included raised levels of IMD in plasma and of expression in the infarcted area. In addition, there was modulation of receptor activity-modifying protein (RAMP)2 and RAMP3 expres-

Professor JJ Evans is at the Department of Obstetrics and Gynaecology, Christchurch School of Medicine and Health Sciences, University of Otago, Christchurch, New Zealand, Centre for Neuroendocrinology, University of Otago, Christchurch, New Zealand and MacDiarmid Institute for Advanced Materials and Nanotechnology, Christchurch, New Zealand

E-mail: john.evans@otago.ac.nz sion. The peptide was administered to consider the effects of IMD, and these included reduction in the size of the necrotic area. Furthermore, levels of IMD in blood were positively associated with diastolic blood pressure and negatively associated with pulse pressure. These results are consistent with a cardioprotective function.

The authors have supplied new information on the response and potential role of IMD in myocardial ischemia-reperfusion injury. This is important in light of the knowledge that there are a number of endogenous bioactive factors involved in cardiovascular control. These include the peptides endothelin-1, CNP, angiotensin-II, urocortin and adrenomedullin (ADM), among others. To understand (and therefore control) the system, it is necessary to delineate the distinct effects of the different peptides. The activities and responses of the peptides will potentially complement each other in physiological functioning by being activated in different circumstances.

The relationship between IMD and ADM is of particular interest because of their structural similarity and the possibility that they comprise a distinct family within the calcitonin gene-related peptide superfamily. ${ }^{3}$ It has been observed that the effects of IMD on the cardiovascular system can indeed sometimes be similar to those of $\mathrm{ADM}$, so perhaps in some circumstances we could expect the effects to be additive in vivo. Even with regard to ischemia-reperfusion injuries, cardio-protective activity has been reported for both ADM and IMD. ${ }^{7}$ The current study has observed that IMD reduces neutrophil infiltration and has an increased presence in ischemic tissue, as does ADM. ${ }^{8,9}$ Nevertheless, these peptides do not always work through the same pathways. For example, the actions of ADM against ischemia-reperfusion injury are strongly influenced by pressure loading, ${ }^{10}$ while expression of IMD is regulated by the extent of myocardial oxidative stress and is reduced by antioxidant therapy. ${ }^{11}$ It has also been observed that IMD and ADM may be differentially affected by regulating factors; furthermore, the two peptides have distinct effects on arterial endothelial cells in vitro. ${ }^{12}$ Although both IMD and ADM interact with all the three RAMPs, the ranked affinities between them differ: ADM has higher agonist activity with RAMP2 or RAMP3 than does IMD. ${ }^{2}$ Thus, the receptor systems provide further means for the differential activity of the two peptides.

There are several reports on the ability of one vasoactive peptide to either stimulate or inhibit the secretion of another. Thus, cardiovascular control is a function of the activities of a community of peptides. As has been illustrated in a number of studies, including this one, expression of related receptor activity is also important. However, there are still large gaps in our knowledge of the combinatorial enhancement or suppression of expression of peptides and their interactive pathways of action in pathophysiological models. Thus, investigations of networks that follow from studies characterizing individual peptides will be important for fully understanding the cardiovascular system.

\footnotetext{
1 Fujisawa Y, Nagai Y, Miyatake A, Miura K, Shokoji T, Nishiyama A, Kimura S, Abe Y. Roles of adrenomedullin 2 in regulating the cardiovascular and sympathetic nervous systems in conscious rats. Am J Physiol Heart Circ Physiol 2006; 290: H1120-H1127.

2 Roh J, Chang CL, Bhalla A, Klein C, Hsu SY. Intermedin is a calcitonin/calcitonin gene-related peptide
} 
family peptide acting through the calcitonin receptor-like receptor/receptor activity-modifying protein receptor complexes. J Biol Chem 2004; 279: 7264-7274.

3 Takei $\mathrm{Y}$, Inoue K, Ogoshi M, Kawahara T, Bannai $\mathrm{H}$, Miyano $S$. Identification of novel adrenomedullin in mammals: a potent cardiovascular and renal regulator. FEBS Lett 2004; 556: 53-58.

4 Hirose T, Totsune K, Mori N, Morimoto R, Hashimoto M, Nakashige $Y$, Metoki $H$, Asayama K, Kikuya M, Ohkubo T, Hashimoto J, Sasano H, Kohzuki M, Takahashi K, Imai Y. Increased expression of adrenomedullin $2 /$ intermedin in rat hearts with congestive heart failure. Eur J Heart Failure 2008; 10 840-849.

5 Bell D, Zhao Y, McCoy FP, Devine A, McDermott BJ. Expression of the counter-regulatory peptide intermedin is augmented in the presence of oxidative stress in hypertrophied cardiomyocytes. Cell Physiol Biochem 2008; 21: 409-420.

6 Zhang H-y, Jiang W, Liub J-Y, Lib Y, Chen C-L, Xin $\mathrm{H}-\mathrm{B}$, Huanga D-J. Intermedin is upregulated and plays protective roles in a mouse ischemia/ reperfusion model. Hypertens Res 2009; 32: 861-868.

7 Yang JH, Qi YF, Jia YX, Pan CS, Zhao J, Yang J, Chang JK, Tang CS. Protective effects of intermedin/adrenomedullin2 on ischemia/reperfusion injury in isolated rat hearts. Peptides 2005; 26: 501-507.

8 Yang J, Wu R, Qiang X, Zhou M, Dong W, Ji Y, Marini CP, Ravikumar TS, Wang P. Human adrenomedullin and its binding protein attenuate organ injury and reduce mortality after hepatic ischemia-reperfusion. Ann Surg 2009; 249: 310-317.

9 Belloni AS, Guidolin D, Ceretta S, Bova S, Nussdorfer GG. Acute effect of ischemia on adrenomedullin immu- noreactivity in the rat heart: an immunocytochemical study. Int J Mol Med 2004; 14: 71-73.

10 Zhao Y, Bell D, Smith LR, Zhao L, Devine AB, McHenry EM, Nicholls DP, McDermott BJ. Differential expression of components of the cardiomyocyte adrenomedullin/intermedin receptor system following blood pressure reduction in nitric oxide-deficient hypertension. J Pharmacol Exp Ther 2006; 316: 1269-1281.

11 Bell D, Zhao Y, McCoy FP, Devine AB, McDermott BJ. Differential effects of an anti-oxidant intervention on cardiomyocyte expression of adrenomedullin and intermedin and their receptor components in chronic nitric oxide deficiency. Cell Physiol Biochem 2007; 20: 269-282.

12 Pearson LJ, Yandle TG, Nicholls MG, Evans JJ. Intermedin (adrenomedullin-2): a potential protective role in human aortic endothelial cells. Cell Physiol Biochem 2009; 23: 97-108. 